\title{
書光光源に關する研究 (IV)*
}

一北天輝度飞就几て一。

正會員，小木曾定彰

（東大建築科特别研究生）

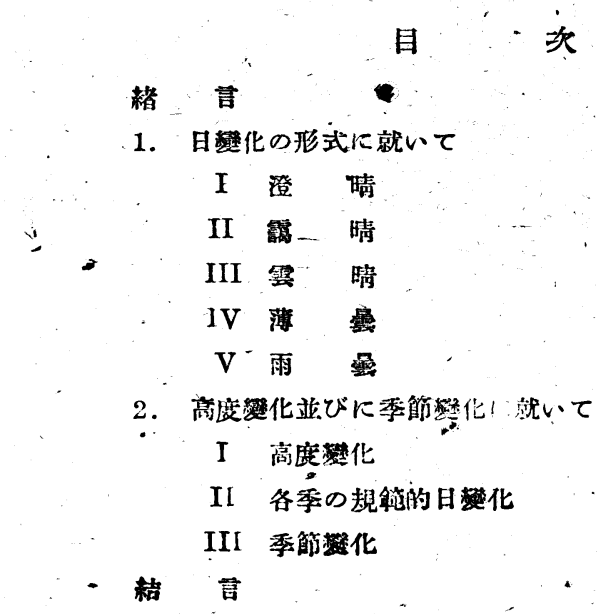

\section{緒・雫}

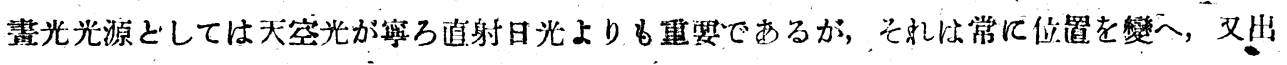

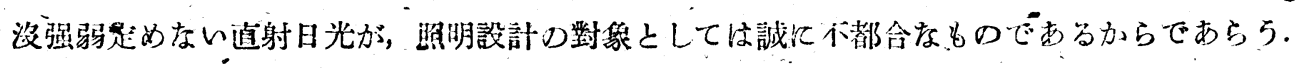
從つて鳌光照明つ設計は天空光を對象として行ひ，赛際上之に加はる直射日光は照明學的には

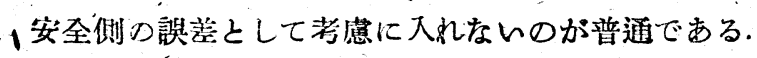

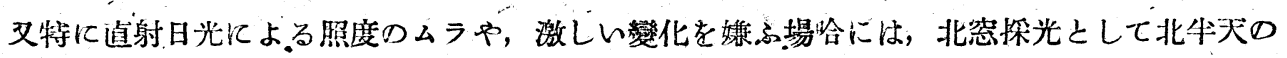

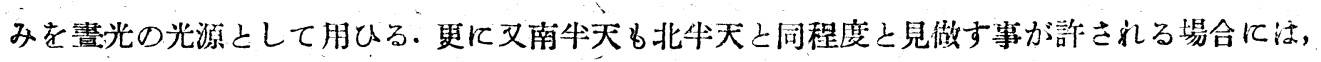
北天理度に上つて南向其他の場哈の探光を荐へる事が出來る. 汃く如くして北牛天D天空辉 度といふものは照明學上重裂な一つの課題であり，特に北天辉度を題目ともた論文も一二見受 けられる所である.(1)

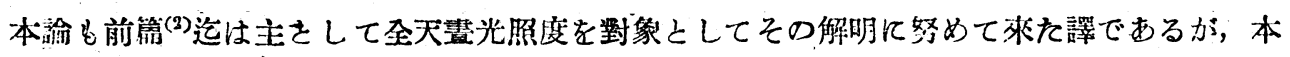

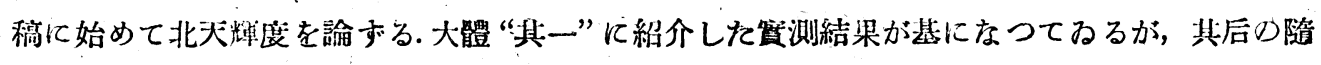

* 抄諭: 本誌䀡和 19 手第 8 號.
(1) Ives \& Knowls その他
(2) 本誌昭 18 年 7 月 


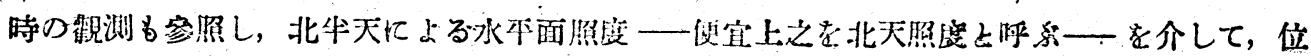

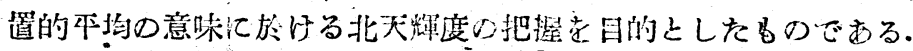

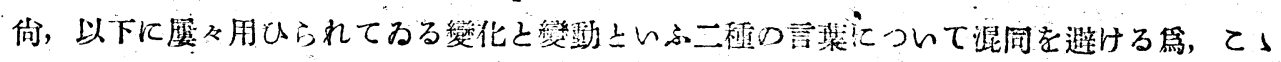

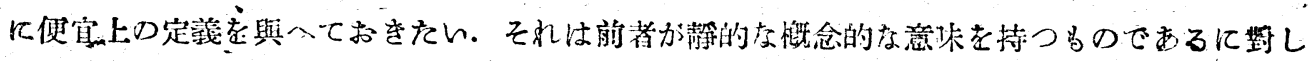

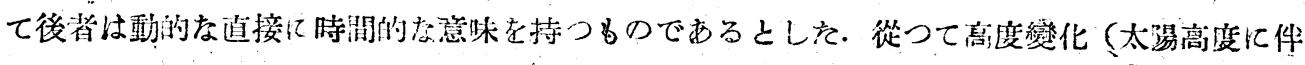

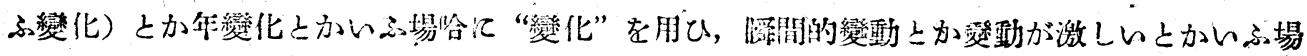

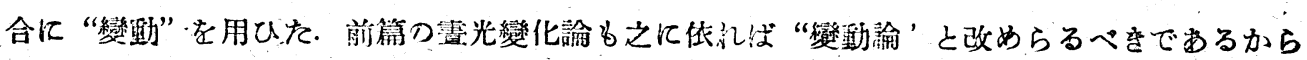
こ」に諽んで訂正をする。

\section{1. 北天照庭日變化わ形式!就いて}

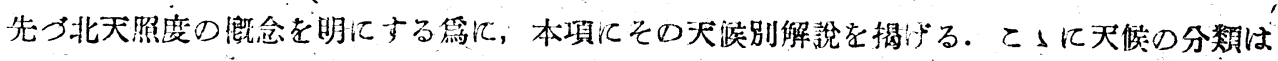

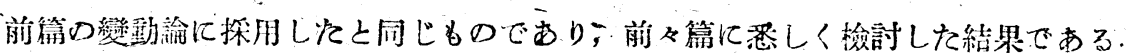

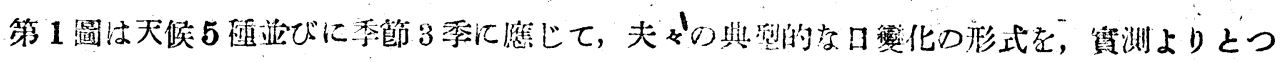
て紹介したものである．以下に個々の場合を分つてその解說をする.

\section{I. . 澄 晴 $\mathrm{A}_{1}$.}

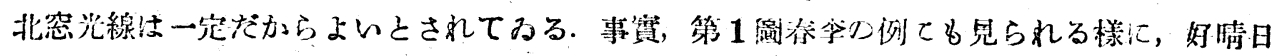

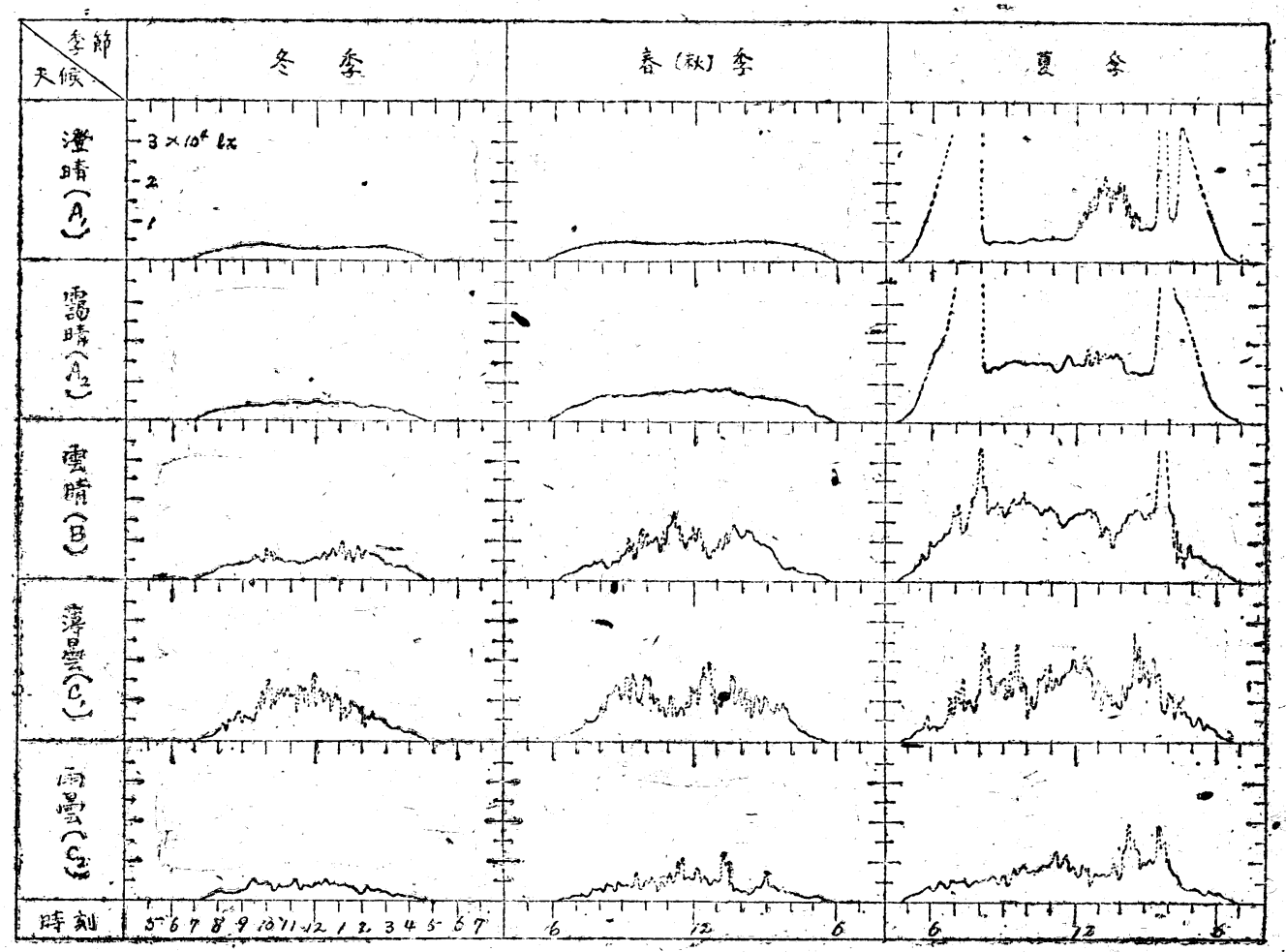

、第 1 圆 北天照度山化の宣測的 
さ毒察よりする北卅天照度は絡日殆んど一定の值を保つてわるが，之は算沉殆んど偶然の絬果

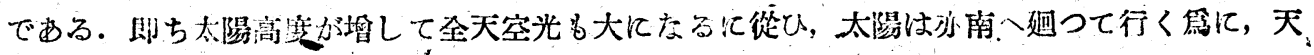
察の中の暗い部分が，北天を掩ふやらになる結果之考八られるのであつて，北天照度が終日一 定であるといふのは實は單一な性筫ではないのでるる。

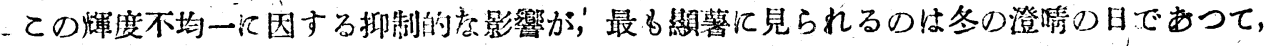

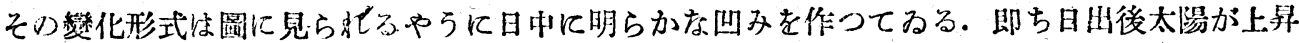
するに從つて天空全能の輝度当燴大して來るが，一方太陽が献に迴るに從つて，太陽を焦點亡

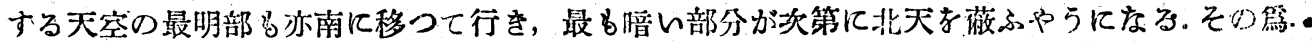
北天照度は或程度からは增さ索くなり，次には幾ら引減じて行つて南中時頃に一つの極小を形

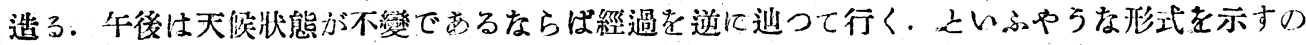

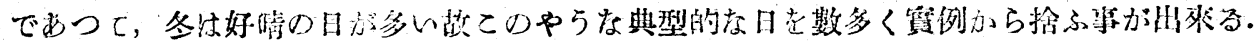

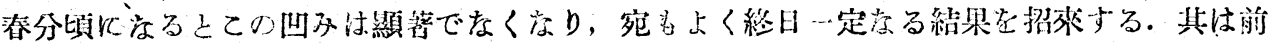

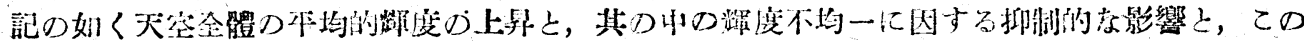

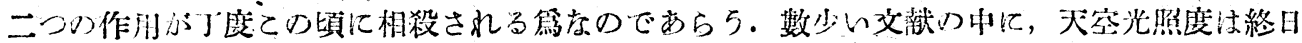

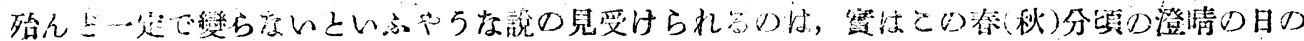

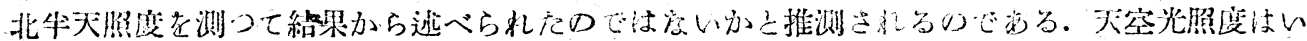

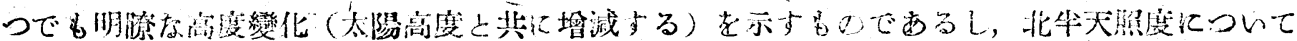

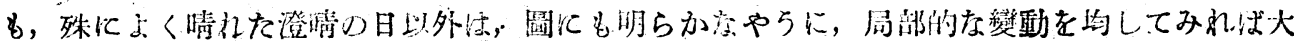

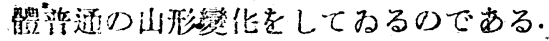

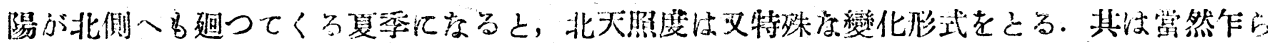

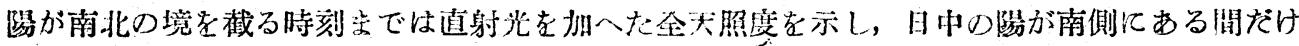
固有の天空光照度を示す結果. 圖の如く不迎續极中凹子の形となる。

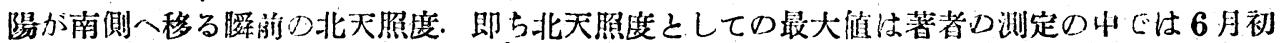

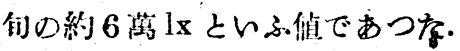

II. 霍 晴

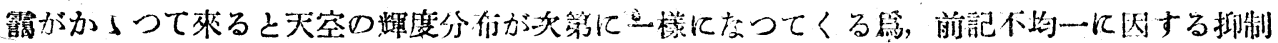

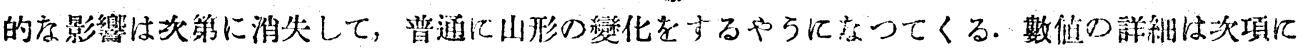

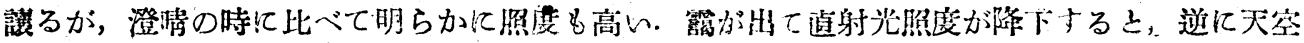

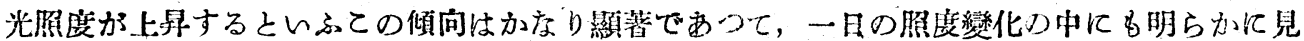

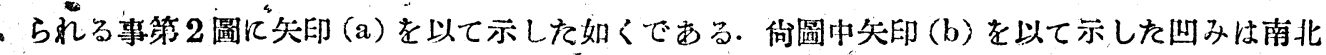

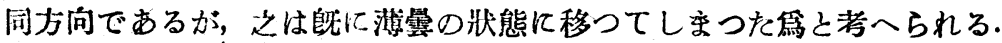

III. 雲

晴

青空に白答の散在する狀態は，天空として最も明るいものとされて來た。 著者の測定絬果は 


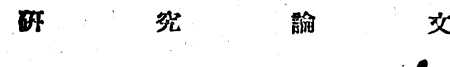

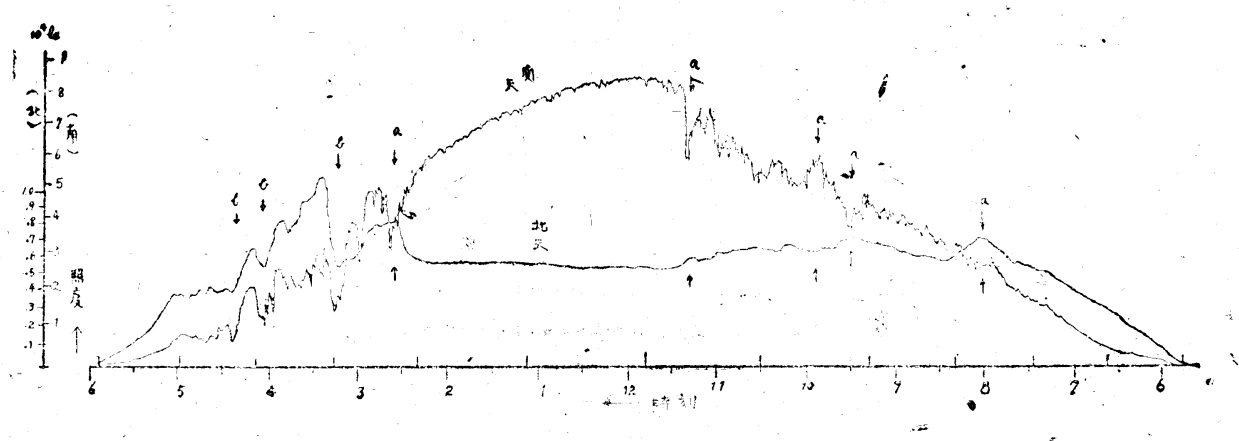

管 2 圆

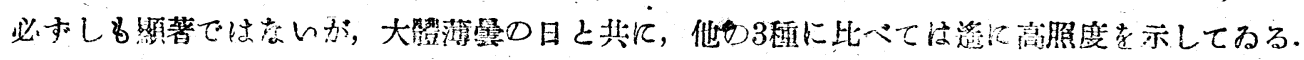

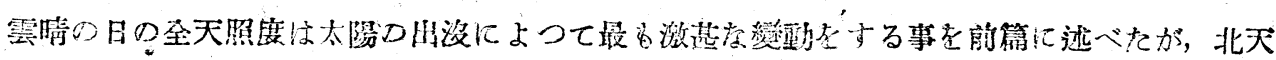

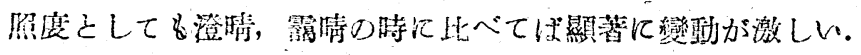

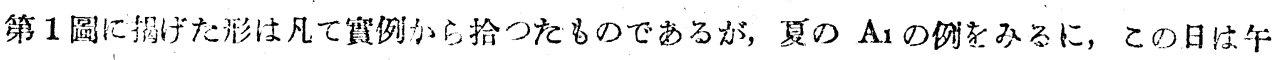

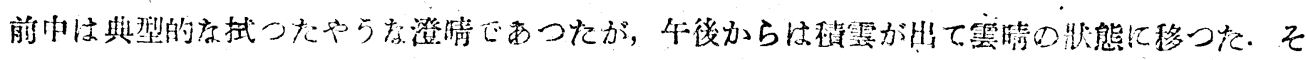

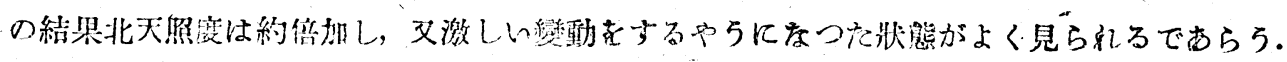

\section{IV. 薄 罢}

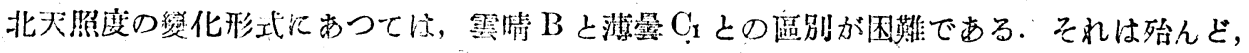

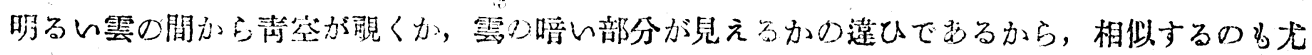

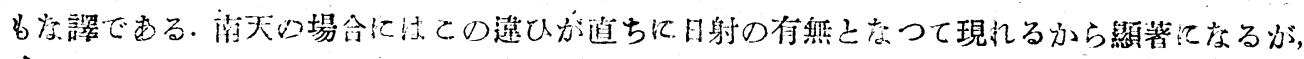

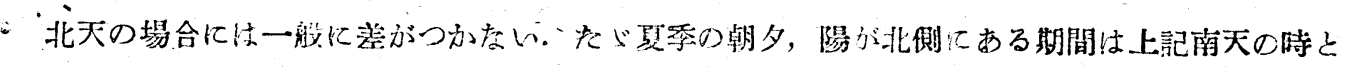

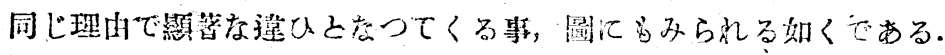

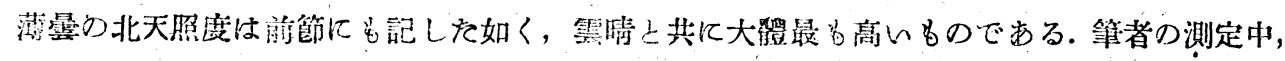

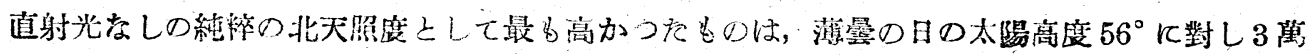

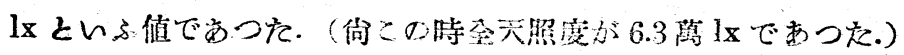

\section{V. 雨 䛒}

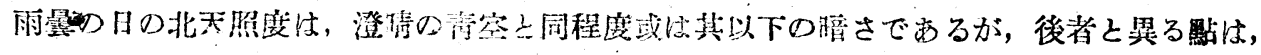

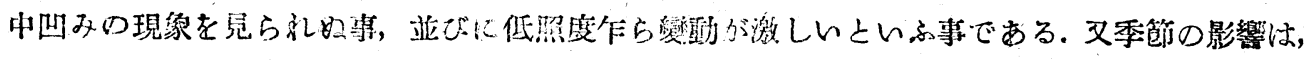

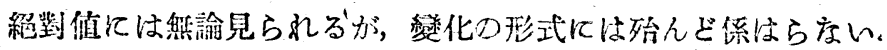

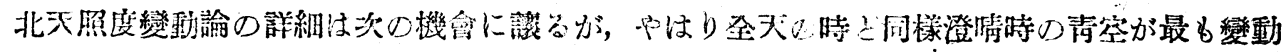

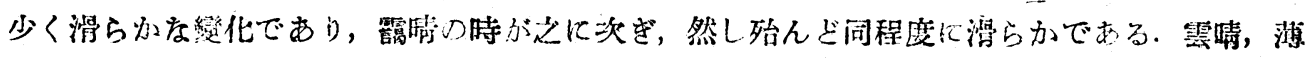

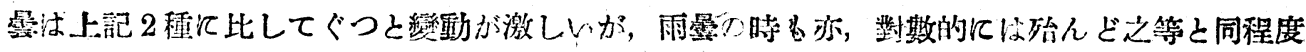

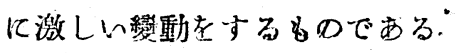




\begin{tabular}{|c|c|c|c|}
\hline & $10^{\circ}$ & $20^{\circ}$ & $30^{\circ}$ \\
\hline$\Lambda_{1}$ & $\begin{array}{l}2.0 \\
2.1 \\
2.3\end{array}$ & $\begin{array}{l}2.4 \\
3.2 \\
3.6\end{array}$ & $\begin{array}{l}2.6 \\
3.0 \\
3.4\end{array}$ \\
\hline$A_{2}$ & $\begin{array}{l}2.1 \\
2.3 \\
2.5\end{array}$ & $\begin{array}{l}3.4 \\
\frac{3.7}{3.7} \\
4.6\end{array}$ & $\begin{array}{l}3.9 \\
4.5 \\
4.9\end{array}$ \\
\hline B & $\begin{array}{l}2.7 \\
3.2 \\
3.5\end{array}$ & $\begin{array}{l}3.9 \\
5.4 \\
6.8\end{array}$ & $\begin{array}{l}4.6 \\
8.2 \\
8.4\end{array}$ \\
\hline $\mathrm{C}_{1}$ & $\begin{array}{l}2.0 \\
2.5 \\
3.3\end{array}$ & $\begin{array}{l}5.5 \\
6.0 \\
6.7\end{array}$ & $\begin{array}{r}6.5 \\
9.7 \\
12.1\end{array}$ \\
\hline $\mathrm{C}_{2}$ & $\begin{array}{l}1.8 \\
2.2 \\
2.6\end{array}$ & $\begin{array}{l}1.7 \\
2.8 \\
4.8\end{array}$ & $\begin{array}{l}2.8 \\
4.2 \\
6.6\end{array}$ \\
\hline 粽 & $\begin{array}{l}1.9 \\
2.4 \\
3.3\end{array}$ & $\begin{array}{l}2.8 \\
3.6 \\
6.0\end{array}$ & $\begin{array}{l}2.9 \\
4.4 \\
8.3\end{array}$ \\
\hline
\end{tabular}

i) 1 月

\begin{tabular}{c|c|c|c|c}
\hline & $10^{0}$ & $20^{\circ}$ & $30^{\circ}$ & $40^{\circ}$ \\
\hline & 1.9 & 2.8 & 3.0 & -3.0 \\
$\mathrm{~A}_{1}$ & 2.7 & 3.5 & 4.0 & 3.2 \\
& 3.4 & 4.3 & 4.8 & 3.5 \\
\hline & 1.9 & 3.4 & 4.6 & 5.2 \\
$\mathrm{~A} 2$ & 2.3 & 4.1 & 5.2 & 5.8 \\
& 3.2 & 6.0 & 5.8 & 6.2 \\
\hline & 1.7 & 3.5 & 5.7 & 7.4 \\
$\mathrm{~B}$ & 2.4 & 4.6 & 7.7 & 9.7 \\
& 3.5 & 5.5 & 10.6 & 11.7 \\
\hline & 2.0 & 4.8 & 5.9 & 7.1 \\
$\mathrm{C} 1$ & 2.9 & 5.8 & 8.1 & 10.9 \\
& 3.8 & 6.8 & 9.9 & 13.1 \\
\hline & 0.6 & 1.0 & 2.0 & 2.6 \\
$\mathrm{C} 2$ & 0.8 & 1.5 & 2.4 & 3.0 \\
& 1.0 & 2.2 & 2.8 & 3.5 \\
\hline & 1.0 & 1.7 & 2.6 & 3.0 \\
綜合 & 2.2 & 3.6 & 4.3 & 5.6 \\
& 3.7 & 6.1 & 9.9 & 12.1 \\
\hline
\end{tabular}

ii) 2 月

\begin{tabular}{|c|c|c|c|c|c|}
\hline & $10^{\prime}$ & $20^{\circ}$ & $30^{\circ}$ & $40^{\circ}$ & $50^{\circ}$ \\
\hline$\Lambda_{1}$ & $\begin{array}{l}2.2 \\
2.8 \\
3.4\end{array}$ & $\begin{array}{r}3.5 \\
4.2 \\
5.5\end{array}$ & $\begin{array}{l}4.4 \\
4.7 \\
6.9\end{array}$ & $\begin{array}{l}4.4 \\
5.0 \\
7.0\end{array}$ & $\begin{array}{l}4.6 \\
5.0 \\
7.5\end{array}$ \\
\hline $\mathrm{A}_{2}$ & $\begin{array}{l}2.5 \\
2.8 \\
3.4\end{array}$ & $\begin{array}{l}3.9 \\
4.9 \\
5.5\end{array}$ & $\begin{array}{l}5.1 \\
6.4 \\
7.9\end{array}$ & $\begin{array}{l}5.7 \\
7.0 \\
8.4\end{array}$ & $\begin{array}{l}6.6 \\
7.4 \\
8.8\end{array}$ \\
\hline B & $\begin{array}{l}1.8 \\
2.5 \\
3.1\end{array}$ & $\begin{array}{l}3.2 \\
4.5 \\
6.8\end{array}$ & $\begin{array}{l}4.1 \\
6.3 \\
8.4\end{array}$ & $\begin{array}{r}6.6 \\
9.4 \\
12.7\end{array}$ & $\begin{array}{r}7.3 \\
11.4 \\
13.5\end{array}$ \\
\hline $\mathrm{C}_{1}$ & $\begin{array}{l}1.2 \\
2.0 \\
3.2\end{array}$ & $\begin{array}{l}2.0 \\
4.9 \\
5.7\end{array}$ & $\begin{array}{r}5.7 \\
9.0 \\
11.5\end{array}$ & $\begin{array}{l}7.8 \\
11.4 \\
13.4\end{array}$ & $\begin{array}{l}6.8 \\
11.3 \\
13.7\end{array}$ \\
\hline $\mathrm{C}_{2}$ & $\begin{array}{l}0.6 \\
1.0 \\
2.2\end{array}$ & $\begin{array}{l}1.2 \\
2.4 \\
3.5\end{array}$ & $\begin{array}{r}2.4 \\
3.4 \\
6.4\end{array}$ & $\begin{array}{l}3.2 \\
4.4 \\
8.0\end{array}$ & $\begin{array}{l}3.8 \\
4.5 \\
9.2\end{array}$ \\
\hline 綜合 & $\begin{array}{l}0.8 \\
2.4 \\
3.4\end{array}$ & $\begin{array}{l}1.4 \\
3.9 \\
6.1\end{array}$ & $\begin{array}{l}3.2 \\
5.8 \\
9.7\end{array}$ & $\begin{array}{r}3.9 \\
6.9 \\
13.2\end{array}$ & $\begin{array}{r}4.4 \\
7.5 \\
12.4\end{array}$ \\
\hline
\end{tabular}

iii) 3 月

\begin{tabular}{|c|c|c|c|c|c|c|c|}
\hline & $10^{\circ}$ & $20^{\circ}$ & $30^{\circ}$ & $40^{\circ}$ & $50^{\prime}$ & $60^{\circ}$ & $70^{n}$ \\
\hline$A_{1}$ & $\begin{array}{l}2.0 \\
2.8 \\
4.0 \\
\end{array}$ & $\begin{array}{l}5.1 \\
5.8 \\
7.0\end{array}$ & $\begin{array}{l}7.2 \\
7.5 \\
7.8 \\
\end{array}$ & $\begin{array}{l}8.7 \\
9.2 \\
9.6\end{array}$ & $\begin{array}{r}7.8 \\
9.5 \\
11.6\end{array}$ & $\begin{array}{r}7.6 \\
8.7 \\
10.5\end{array}$ & $\begin{array}{r}8.7 \\
9.9 \\
12.1\end{array}$ \\
\hline$A_{2}$ & $\begin{array}{l}2.4 \\
3.2 \\
4.4 \\
\end{array}$ & $\begin{array}{l}5.6 \\
7.0 \\
8.5 \\
\end{array}$ & $\begin{array}{r}8.3 \\
10.5 \\
13.3 \\
\end{array}$ & $\begin{array}{r}9.4 \\
12.8 \\
16.2\end{array}$ & $\begin{array}{r}9.4 \\
12.0 \\
14.6\end{array}$ & $\begin{array}{r}9.2 \\
11.9 \\
13.9\end{array}$ & $\begin{array}{l}10.0 \\
11.6 \\
13.5\end{array}$ \\
\hline$n$ & $\begin{array}{l}3.0 \\
3.7 \\
4.7\end{array}$ & $\begin{array}{r}5.8 \\
8.1 \\
10.4 \\
\end{array}$ & $\begin{array}{l}10.3 \\
13.2 \\
15.3 \\
\end{array}$ & $\begin{array}{l}13.4 \\
15.8 \\
18.2\end{array}$ & $\begin{array}{l}12.7 \\
16.2 \\
20.4\end{array}$ & $\begin{array}{l}13.0 \\
16.6 \\
20.2\end{array}$ & $\begin{array}{l}15.1 \\
20.2 \\
27.3\end{array}$ \\
\hline $\mathrm{C}_{1}$ & $\begin{array}{l}1.0 \\
2=9 \\
4.8\end{array}$ & $\begin{array}{r}1.8 \\
7.0 \\
13.4\end{array}$ & $\begin{array}{r}6.0 \\
10.3 \\
17.1\end{array}$ & $\left|\begin{array}{r}6.0 \\
12.5 \\
21.4\end{array}\right|$ & $\begin{array}{r}8.1 \\
15.2 \\
25.5\end{array}$ & $\begin{array}{l}12.9 \\
18.4 \\
23.5\end{array}$ & $\begin{array}{l}12.0 \\
17.5 \\
25.0\end{array}$ \\
\hline $\mathrm{C}_{2}$ & $\begin{array}{l}0.6 \\
1.8 \\
2.3 \\
\end{array}$ & $\begin{array}{l}1.0 \\
2.3 \\
3.8\end{array}$ & $\begin{array}{l}2.2 \\
4.9 \\
9.8\end{array}$ & $\left|\begin{array}{r|}2.5 \\
7.2 \\
14.3\end{array}\right|$ & $\begin{array}{r}3.5 \\
7.5 \\
10.6\end{array}$ & $\begin{array}{r}4.4 \\
8.0 \\
13.4\end{array}$ & $\begin{array}{r}6.0 \\
7.4 \\
16.2\end{array}$ \\
\hline 綵合 & $\begin{array}{l}0.8 \\
3.1 \\
4.8\end{array}$ & $\begin{array}{r}1.1 \\
7.3 \\
13.2\end{array}$ & $\begin{array}{r}2.4 \\
10.2 \\
16.8\end{array}$ & $\begin{array}{r}2.5 \\
12.9 \\
21.0\end{array}$ & $\begin{array}{r}4.2 \\
13.0 \\
25.4\end{array}$ & $\begin{array}{r}4.7 \\
14.1 \\
23.3\end{array}$ & $\begin{array}{r}6.2 \\
14.8 \\
25.9\end{array}$ \\
\hline
\end{tabular}

iv) 5 月

\begin{tabular}{|c|c|c|c|c|c|c|c|}
\hline & $10^{\circ}$ & $20^{\circ}$ & $30^{\circ}$ & $40^{\circ}$ & $50^{\circ}$ & $60^{\circ}$ & $70^{\circ}$ \\
\hline$\Lambda_{1}$ & $\begin{array}{l}2.6 \\
2.9 \\
3.3\end{array}$ & \begin{tabular}{r|}
4.1 \\
5.3 \\
7.1
\end{tabular} & $\begin{array}{l}5.3 \\
7.1 \\
9.2\end{array}$ & $\begin{array}{r}5.7 \\
8.5 \\
11.7\end{array}$ & $\begin{array}{r}5.7 \\
9.0 \\
13.2\end{array}$ & $\begin{array}{r}5.7 \\
9.8 \\
15.2\end{array}$ & $\begin{array}{r}6.3 \\
10.4 \\
16.5\end{array}$ \\
\hline$\Lambda_{2}$ & $\begin{array}{l}2.2 \\
2.9 \\
4.3\end{array}$ & $\begin{array}{l}5.4 \\
5.9 . \\
6.7\end{array}$ & $\begin{array}{l}7.4 \\
8.3 \\
8.9\end{array}$ & $\begin{array}{l}10.6 \\
11.5 \\
12.2\end{array}$ & $\begin{array}{l}11.2 \\
11.9 \\
13.2\end{array}$ & $\begin{array}{r}9.8 \\
12.2 \\
15.1\end{array}$ & $\begin{array}{r}9.6 \\
12.6 \\
16.5\end{array}$ \\
\hline B & $\begin{array}{l}1.4 \\
3.7 \\
5.5\end{array}$ & $\begin{array}{l}3.2 \\
6.5 \\
9.3\end{array}$ & & & $\begin{array}{l}14.3 \\
17.8 \\
22.0\end{array}$ & $\begin{array}{l}14.9 \\
19.9 \\
24.5\end{array}$ & $\begin{array}{l}12.4 \\
19.2 \\
23.9\end{array}$ \\
\hline $\mathrm{C}_{1}$ & $\begin{array}{l}1.4 \\
3.2 \\
5.0\end{array}$ & $\begin{array}{l}2.2 \\
6.7 \\
9.7\end{array}$ & $\begin{array}{r}2.8 \\
9.4 \\
14.8\end{array}$ & $\begin{array}{r}5.7 \\
11.3 \\
17.3\end{array}$ & $\begin{array}{r}8.3 \\
14.8 \\
20.4\end{array}$ & $\begin{array}{r}10.2 \\
19.5 \\
28.6\end{array}$ & $\begin{array}{l}10.5 \\
19.2 \\
26.0\end{array}$ \\
\hline $\mathrm{C} 2$ & $\begin{array}{l}0.8 \\
1.9 \\
3.3\end{array}$ & $\begin{array}{l}1.5 \\
3.1 \\
4.7\end{array}$ & $\begin{array}{l}1.8 \\
4.7 \\
8.8\end{array}$ & $\begin{array}{r}3.1 \\
6.5 \\
10.8\end{array}$ & $\begin{array}{r}4.2 \\
8.1 \\
12.5\end{array}$ & $\begin{array}{r}3.8 \\
8.4 \\
11.8\end{array}$ & $\begin{array}{r}4.8 \\
9.8 \\
18.9\end{array}$ \\
\hline 綜合 & $\begin{array}{l}0.9 \\
3.1 \\
5.3\end{array}$ & $\begin{array}{l}1.7 \\
5.7 \\
9.3\end{array}$ & $\begin{array}{r}2.1 \\
7.5 \\
15.3\end{array}$ & $\begin{array}{r}3.7 \\
11.0 \\
17.7\end{array}$ & $\begin{array}{r}4.6 \\
11.7 \\
20.7\end{array}$ & $\begin{array}{r}4.4 \\
13.2 \\
24.5\end{array}$ & $\begin{array}{r}6.2 \\
11.5 \\
25.4\end{array}$ \\
\hline
\end{tabular}

v) 6 月

筇 1 装，北天照度

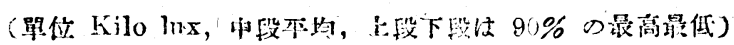




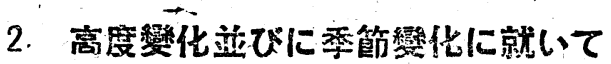

\section{I. 高 度 變 化}

全天照度は太陽高度と天氣狀態といふ二つの變數によつて，變舫の幅は廣いが少くも理論的 に略適確に把握出來たのであるが，北天照度てついては，已に度及縲說したやらに之等に更

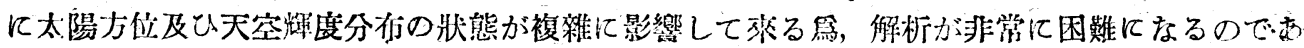
るが，短期閒例へばー月每の記錄を探つて考へるならば，其は略始めの變嫩によつて整理し得 る.

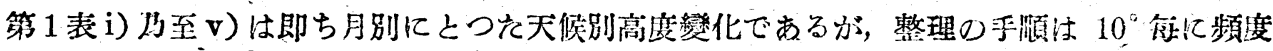
曲線老描的の平均之Mi 中 心 $90 \%$ の範圍をとろ事，全天 照度の場合(2)江準和る。但し夏 季の陽が北澌へ画つた時つ不連 續な變化につ的ては，ての部分 だけ南天照度を以て置き換へて 侤へる事ししをてそれは本論の 日的为本均(位置的)北天歯度の 考些にある所加ら，㨁射光の加。 はつた北天照度恔外与る事外 帘笛上考入られたからである。 第3圖の例江見ら机る如く太陽

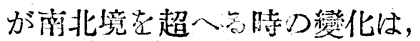
南天が北天，北天有南天几夫々

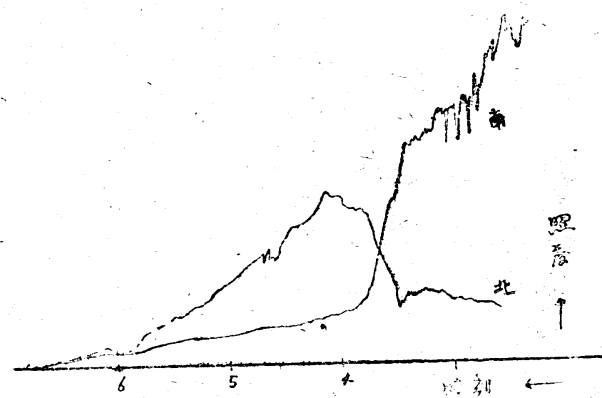

第 3 活

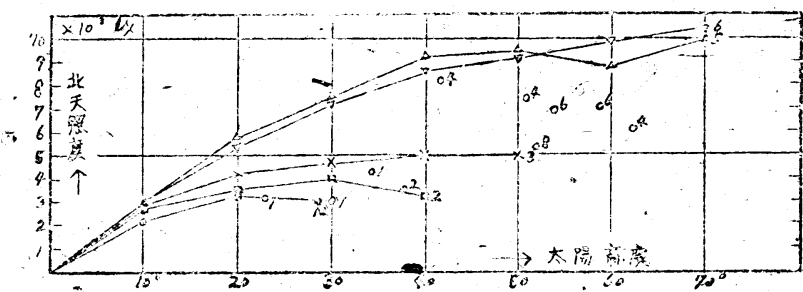

(i) 澄碃A

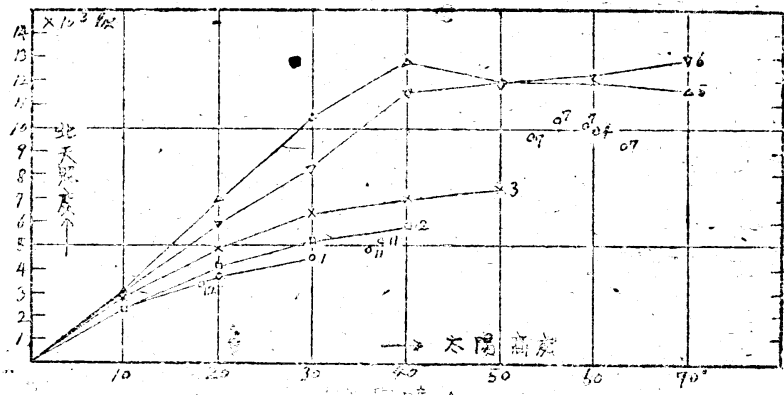

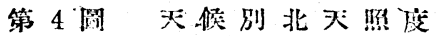
續く形沉をるのでする。而してて 本回埰用し它形安乙の中下例方 献北接續曲線であつて，正しく は太陽のなない侧の坐天の照度 を檢討した譯でする。

次心第 4 渭(i) ( v) 性第 1 表 の結果を天候別に配列した多の であるが，こ」には連緽测定

(3) 本諭其 2 : 本誌畹科 18 得 3 月

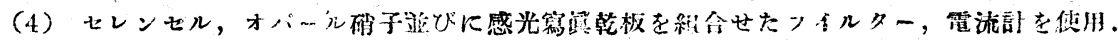




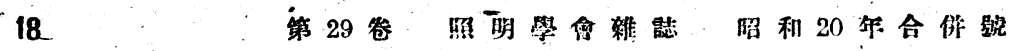

- (第 2 次測定)以後のやはり光電 的にな、された采隨時の测定絬果 を○印で示してある．佾修の數 字は月數である.

之等の圖によつて見るに，大 體。 $\mathrm{C}_{1}$ 及び $\mathrm{C}_{2}$ の高度變化には季 節の影蠁が少くて殆んど 1 本の カーヴに沿ふと見索されるが， 他の $A_{1}, A_{2}, B$ の高度變化には 明嘹に季䈱の影響が見出される。 即ち5月と6月との關係並びに

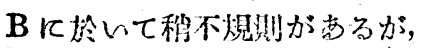
大體1月から6月まで柔統的比 カーヴは上景して居り,同じ $30^{\circ}$ の時でも1月の北㤁照度よりは。 6 月の娎の方が遥に大であると いふ如を結果走してるる。方

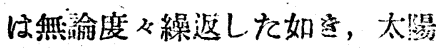

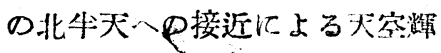
度分布の移動が原因で焉る之洘 へられる。 5 月を 6 月の曲線つ 交錯多亦，乙の太隄位置の考察

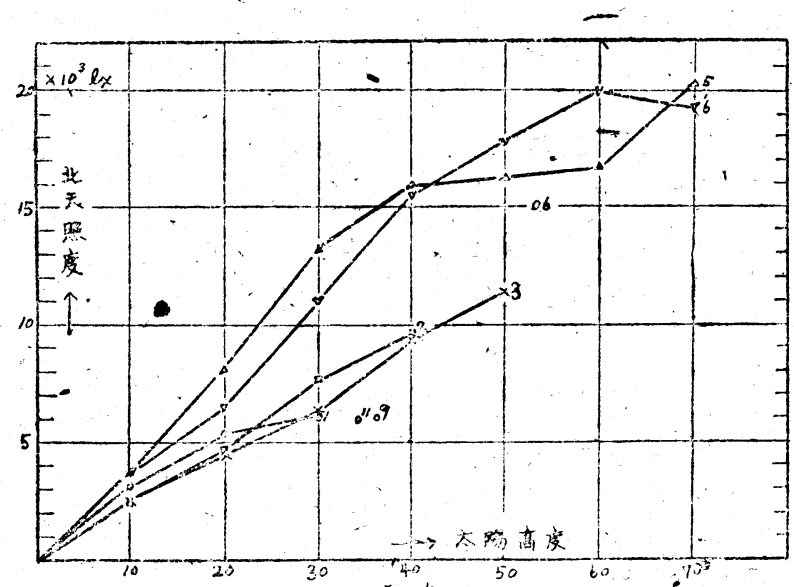

(iii) 筑晴, B

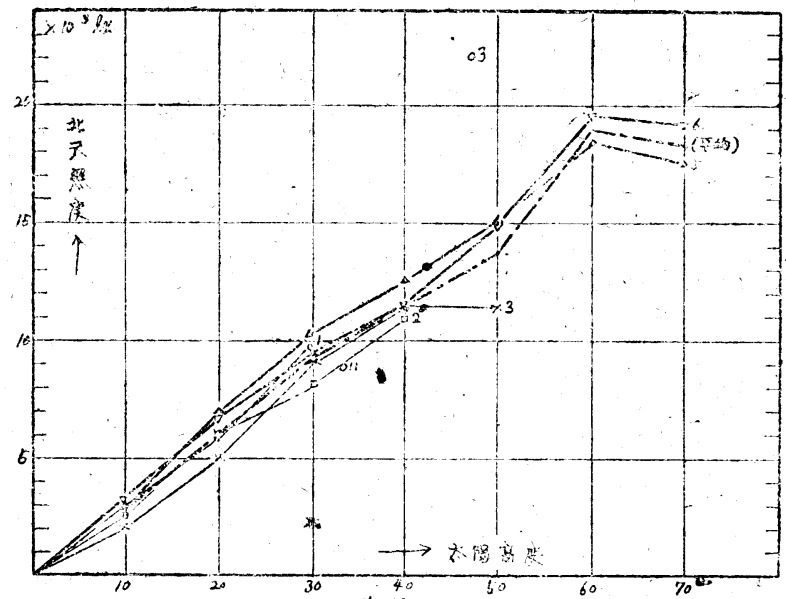

(ii) 薄显 $C^{\prime}$ ，

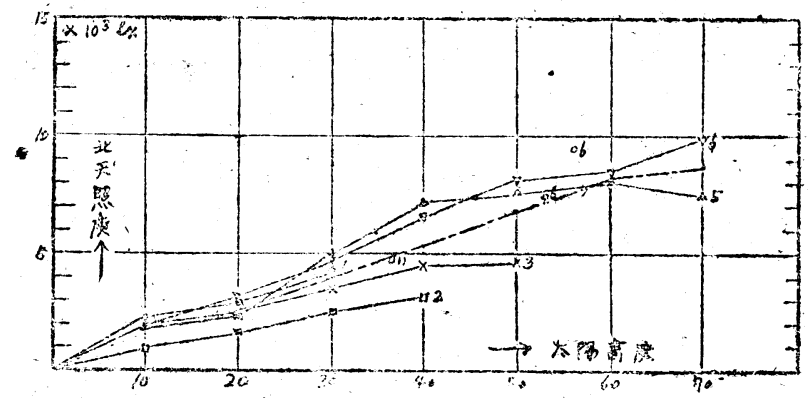

V) 雨 冡 $\mathrm{C}_{2}$

第 4 圆。 籍的日變化古描んたのが籍 5 圖

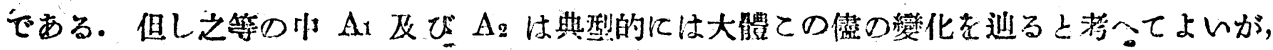

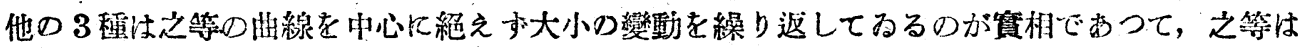
・前篇の變動論に上るば各天候に對する正規變化を表するのである。 
III 季第繁化仁

\section{就いて}

日變他の形に期へる季

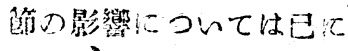
前公に站へた所吉る

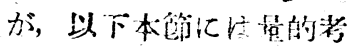

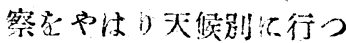
てみる。

その篇先づ一日の代表

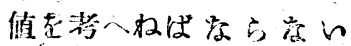

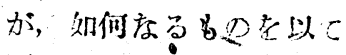

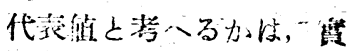

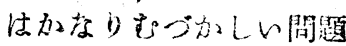
でする。一般てもり

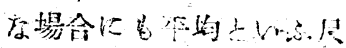

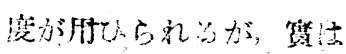

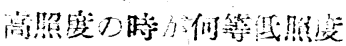

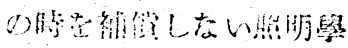

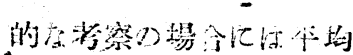

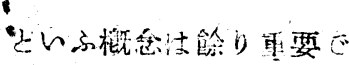

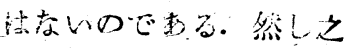

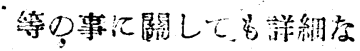

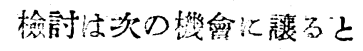
して今行只北天照度の如

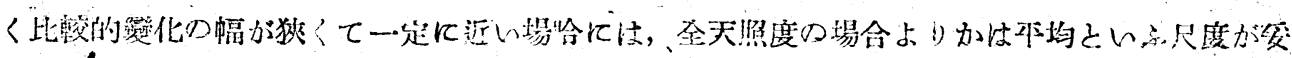

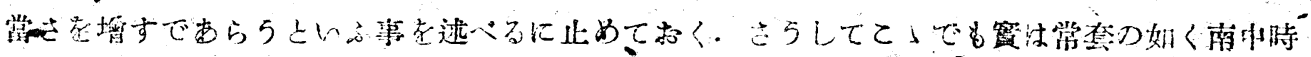

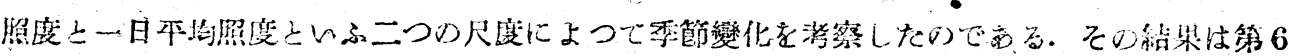

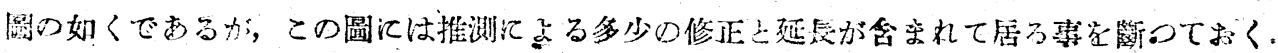

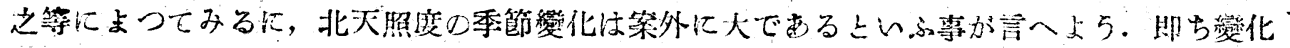

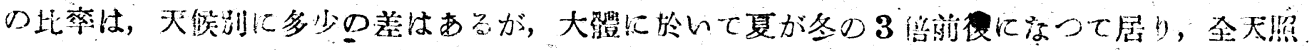

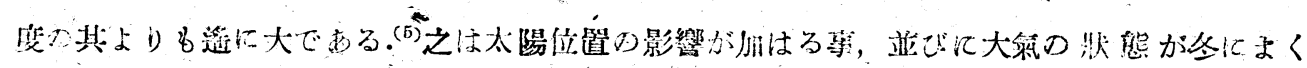

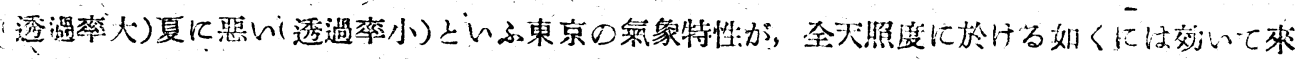

(5) 本諭其 1 本誌昭和 17 年 5 月习答照 


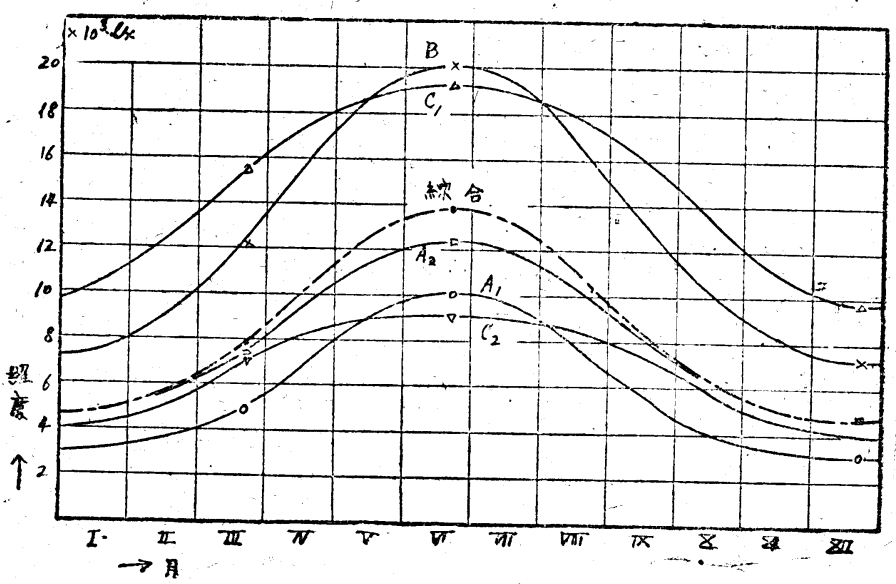

i) 南中時

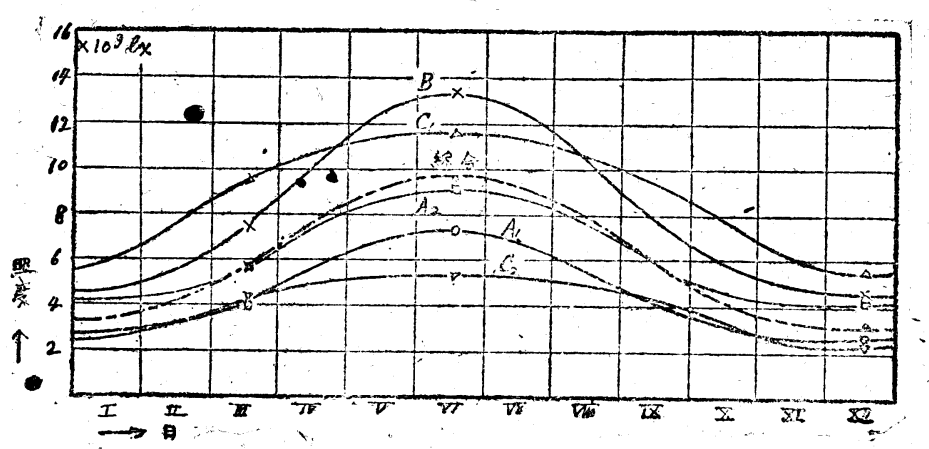

ii) 日本均

第 6 圆北天照度，季節化

ない䉆と拷へられる。

\section{結語}

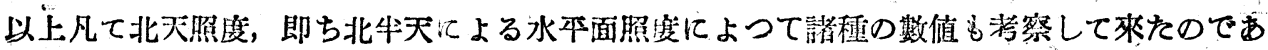

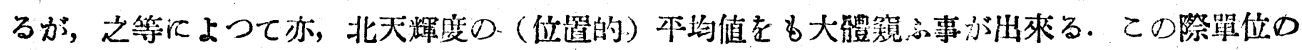

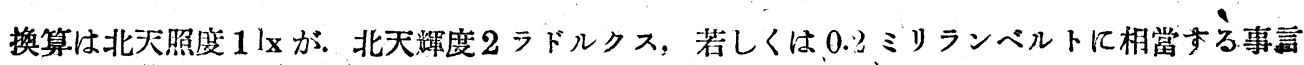
ふまでもない.

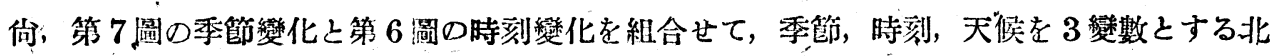
天輝度，從つて北天辉度の略掺式を作る事が可能で索るが，必要な數值の精度低さに拘らず式 ，の形が複雜であるのは，危險な意味があるので發表を控へる事とした。（20-8-1 受付） 